\title{
FRANK S. BREWER 1948 PRIZE
}

Under the bequest of Frank S. Brewer, the American Society of Church History awards a prize of $\$ 500.00$ toward the expense of publication of a winning essay, whenever the income of this fund permits.

The next contest will close on June 1, 1948. On or before this date essays offered in competition must be in the hands of the Secretary of the Society.

In order to be considered for this prize, the manuscripts must be in typed form, properly documented, and ready for submission to the printer.

Raymond W. Albright, Secretary, 1524 Palm Street, Reading, Penna. 